\section{Archaeology of Architecture and Archaeology of houses in Early Medieval Europe}

\section{Arqueología de la Arquitectura y Arquitectura doméstica en la alta Edad Media europea}

Juan Antonio Quirós Castillo*

Universidad del PaísVasco. UPV/EHU

\begin{abstract}
This paper aims to introduce the «Archaeology of Architecture and Household Archaeology in Early Medieval Europe» dossier, the object of which is to explore the different approaches, methodologies and themes analysed in the study of early medieval architecture in western Europe. More specifically, in what follows, analysis is undertaken of the contexts which explain the recent development of studies on this topic, as well as the main contributions of the seven papers which form this dossier. In addition, the main historical and archaeological problems raised by the analysis of this material record are also discussed.
\end{abstract}

Key words: Building Archaeology, Household Archaeology, Processual approach, Postprocessual approach, Longhouse, Sunken-Feature Buildings.

\section{Resumen}

En este trabajo se presenta el dossier «Archaeology of Architecture and Household Archaeology in Early Medieval Europe», que pretende explorar los distintos enfoques, metodologías y temáticas analizadas en el estudio de las arquitecturas altomedievales en el marco de Europa occidental. Más concretamente se analizan los contextos que explican el desarrollo reciente de los estudios sobre esta materia, las principales aportaciones de los siete trabajos que conforman este dossier y se discuten los principales problemas históricos y arqueológicos que plantea el análisis de este registro material.

Palabras claves: Arqueología de la Construcción, Arqueología de la casa, Procesualismo, Posprocesualismo, Longhouse, Fondos de cabaña.

\section{* quiros.castillo@ehu.es}

The present contribution is part of the research project funded by the Spanish Minister of Research "The Formation of Medieval Landscapes in the Northern Peninsula and Europe», HUM2009-07079, and the activity of the 'Heritage and Cultural Landscape Research Group' funded by the Basque Government (IT315-10) and the UFI 'History, Thought and Material Culture' (UFI2011/ 02).
1. Some years ago I prepared a monographic dossier dedicated to the study of medieval building techniques for the fourth issue of the journal 'Arqueología de la Arquitectura' (Azkarate, Quirós Castillo 2005). The objective was to collect together a series of articles which stimulated analysis and debate in relation to one of the most interesting topics then being tackled by the archaeology of architecture, and to propose a platform from which the instrumental reductionism with which some then treated the discipline might be overcome. The project underlying our journal, after its subsequent renovation, has been notably consolidated and enriched, incorporating new themes and experiences, as readers of our most recent editions will have been able to observe. The motivation behind the preparation of this dossier has been that of broadening the questions that the journal approaches so as to include 'other architectures' which have not until now featured greatly in its pages, and of stimulating the analysis of domestic material registers not characterised by their monumentality, from a broad European perspective. Ours is not an isolated case, and, for example, for some years now in Italy the term 'Archaeology of architecture' has been substituted by that of 'Archaeology of architectures', with the aim of embracing other building systems which periodically escape conventional analytical frameworks. In some archaeological traditions, indeed, the very notion of Archaeology of Architecture is primarily identified with the study of domestic architecture (e.g. Steadman 1996, Sánchez 1998; Zarankin 1999).

With the aim of delimiting and giving coherence to the contents of this dossier we have chosen as our chronological framework the early Middle Ages ( $5^{\text {th }}$ to $10^{\text {th }}$ centuries), given that it was a period in which a profound transformation took place both in forms of dwelling and construction; this selection has been made in order that the study of its architecture can help us to put to the test the conceptual and methodological instruments of historical and archaeological analysis applied elsewhere to the analysis of other architectures. Our study deals, moreover, with a subject matter that currently lacks a Europe-wide synthesis, although national and regional studies have demonstrated the existence of strong patterns that act on a very wide scale (e.g. Klápště, Nissen Jaubert 2007, 85 ss.).

On the other hand, in the last few years a multiplication of studies on the domestic architecture of this period has been produced, due, amongst other things, to the notable development that the practice of preventive archaeology has achieved, and to the undertaking of large archaeological projects against the backdrop of a phase of 
expansion which has characterised the European economy in recent years. Never had so many sites been destroyed in so little time, but nor had there ever been so much excavation. All these records, still in the process of elaboration and assimilation after the shock provoked by the financial crisis and the application of the brakes to the practice of preventive archaeology, are allowing for the critical revision of problems such as the social, political and economic transformation that took place in the postImperial period, the role of barbarians in the structures of early medieval landscapes, the forms of representation manifested by social hierarchies, and, to some extent, the very process of the construction of a common European identity, to which B. Ward-Perkins $(2005,172)$ has recently drawn our attention. As a consequence of all of the above, another important new finding to have come about in the last few years is the discovery of early medieval architectures in the south of Europe with similar characteristics in formal, technological and functional terms to those found in other parts of the continent. In contrast to the north and centre of Europe, where studies of domestic early medieval architectures can be traced back to the first decades of the twentieth century (see Gardiner, Peytremann, Schreg) and for which areas we have at our disposal significant syntheses and monographical studies, archaeology in southern Europe has approached this subject matter for a relatively short period of time ${ }^{1}$. In fact, in the influential synthesis on early medieval villages and dwelling places published by J. Chapelot and R. Fossier in 1980 no space was afforded to sites located on the shores of the Mediterranean (Chapelot, Fossier 1980, 79 ss.).

In the Italian case, at the end of the 1970s an important role was played by the at the time surprising discovery of modest domestic buildings in the midst of the forum of the Roman city of Luni, although some earlier investigations had been undertaken, above all on the back of written documentation (Santangeli Valenzani 2011, 9-14). Since then the systematic analysis of buchi di palo and other forms of architecture has played a central role in the study of the process of the formation of early medieval villages (Francovich, Hodges, 2003) or the transformation of the post-Imperial city (Brogiolo, Gelichi 1998; Brogiolo 2011). The critical mass of available

\footnotetext{
${ }^{1}$ The bibliography is abundant, although amongst recent studies which deserve mention are: Peytremann 2003 for the north of France; Hamerow 2002 for the northwest of Europe; Hamerow 2011 y 2012 for Anglo-Saxon England; O'Sullivan et alii 2010 and Jones 2012 for Ireland or the work of Donat 1980 and Zimmerman 1992, 1998 for the German area. For central and eastern Europe see Buko 2010 and Klápště 2002.
}

registers in Italy today is such that several reference studies have been carried out. ${ }^{2}$

In Spain, preventive archaeology has played a fundamental role in the recognition and study of early medieval domestic architectures, especially those constructed in ephemeral materials. Although some stone domestic structures have already been identified throughout the second half of the twentieth century, only since the 1990s have the first semi-excavated constructions, delimited by postholes, been identified, above all in the outskirts of cities. The significant qualitative step forward took place in the 1990s, such that La Indiana or Gózquez in Madrid, the interventions in Vallés (in the Barcelona area) or the project of the cathedral of Vitoria-Gasteiz were some of the pioneering sites in which these types of architectures were identified. Likewise, other archaeological projects, like those of El Tolmo de Minateda or Cerro de Peñaflor, have notably broadened our frame of reference ${ }^{3}$. And although we still lack territorial syntheses, the critical mass of data has grown in striking fashion in recent years ${ }^{4}$.

In Portugal, on the other hand, the first finds coming to light truly are 'invisible constructions', given that houses and other such spaces characterised by domestic material vestiges are being identified but such cases lack material elements which allow us to demarcate buildings (plinths, channels, post-holes) (Tente 2011).

2. The dossier is composed of a total of seven studies which have been commissioned with the aim of providing a broad geographical representation of western Europe by way of territorial syntheses, but also in order to offer a wide and multifaceted framework with regard to theoretical approaches, analytical methodologies and results obtained.

Greater weight has been given to Iberian examples, given that this is the territory that currently lacks studies aiming at synthesis. The three studies included here (on Iberia) demonstrate, in paradigmatic form, the richness of approaches that characterises the study of this architecture.

\footnotetext{
2 On the excavations in Luni, Ward-Perkins 1981; on domestic architecture in Italy see the work of Brogiolo 1994; Galetti 2011; Fronza 2011; Santangeli Valenziani 2011, all of which utilise prior studies.

3 On La Indiana, Vigil-Escalera Guirado 1999; on Gózquez, Vigil-Escalera Guirado 2000; for Catalonia see Roig 2009 and Beltrán de Heredia 2009; for Gasteiz, Azkarate Garai-Olaun, Solaún 2009; for El Tolmo de Minateda, Gutiérrez Lloret 2000, Cañavate Castejón 2008 and Gutiérrez Lloret and Cañavate Castejón 2010; for El Cerro de Peñaflor Salvatierra, Castillo Armenteros 2000. For the Byzantine area see Vizcaíno 2009, 387-403.

${ }^{4}$ See, for example, Azkarate, Quirós Castillo 2001; Vigil-Escalera Guirado 2003; Quirós Castillo 2011.
} 
The structuralist approach followed by Sonia Gutiérrez proposes to undertake an analysis of the early medieval and Islamic domestic phenomenon on three different levels (morphological, syntactical and semiotic) and offers intriguing results when it comes to our conception, in diachronic and cultural terms, of the formative processes of domestic spaces in the Iberian Peninsula. In his study of the north-western quadrant of the peninsula, Carlos Tejerizo processes and systematises, for the first time, results obtained from an important number of preventive archaeological interventions, and he makes recourse to a materialist approach when interpreting the diversity of systems of construction that he detects. Equally suggestive is the contribution of Alfonso Vigil-Escalera, centred on hearths and ovens, which proposes an analysis of domestic space and dwellings not solely defined by vertical structures, walls and plinths, but by interactions engendered by the functioning of daily activities 5 .

The rest of the contributions are structured with reference to much wider territorial syntheses. Giovanna Bianchi, in her discussion of early medieval Italian dwelling spaces dedicates much space to typological and constructive aspects, but her reflections on the forms of dwelling and her analysis of domestic architecture in social terms both lend the piece an assuredly innovative attribute. The apparent contrast manifested by the homogeneity of types of construction with social diversity, as evidenced by various sources, is explained in convincing fashion by the central significance given to the forms of dwelling as opposed to the forms of building, which has been the preeminent approach of the practitioners of archaeology.

Edith Peytremann, the author of an seminal doctoral thesis on the rural settlement of northern France (Peytremann 2003) organises her study in three parts; first, she undertakes a critical evaluation of the historiography; second, she considers the principal themes analysed in France (the tradition of studies on rural architecture; the birth of the village; the integration of bioarchaeological registers; the 'social reading' of the register in hierarchical terms; new approaches to domestic space) and lastly she suggests some case studies by way of example.

Mark Gardiner firstly discusses the five approaches that have been followed in Great Britain in the study of this architecture (the regressive approach, the study of waterlogged structures, the reproduction of woodcraft, experimental reconstruction and the study of archaeologi-

5 This centrality has been equally emphasised in the study of prehistoric domestic architecture (Vela Cossío 1995, 260-261). cal excavations) and he goes on to analyse the ethnic dimension of the different recognised traditions of building, as well as the regional and constructive diversity documented on the islands. Lastly, Rainer Schreg carries out an interesting historiographical analysis of the study of rural settlement and early medieval domestic architecture in Germany, relativising the importance of ethnic traditions and information provided by written documentation. Then he studies the principal types of construction, differentiating between main houses, 'functional' buildings (which served some economic purpose) and constructions designed to demarcate (such as fences), all the while stressing regional differences. He concludes his study by reminding us of the need to analyse in greater detail spatial organisation, forms of dwelling, and social hierarchies, by means of the realisation of studies based on phosphate analysis and the systematic treatment of the bioarchaeological record.

3. The framework proposed by all of these studies is multifaceted and striking, due to the fact that they synthesise the fundamental achievements of the different traditions of national studies, propose significant trans-territorial analogies and differences, and suggest new avenues of future development. Accordingly, it is befitting to underline some of the principal lines of discussion.

First, the role of preventive archaeology has been fundamental to the rising number of studies on early medieval domestic architecture which we have seen throughout all of western Europe in recent decades, although perhaps its impact has been more important in the south of the continent. While the British Isles or the centre of Europe could already lay claim to a tradition of studies on early medieval domestic architecture based on the utilisation of myriad approaches and instruments of analysis (such as regressive approach, experimental archaeology, etc.), in Spain and in other countries the practice of preventive archaeology has been the catalyst for the appreciation of this sort of architecture because it has allowed for the analysis of extensive areas of villages and towns. As a consequence, the different ways of managing archaeological heritage, which differ greatly from one European country to the next (and even from one region to the next within these countries), have conditioned the study of domestic architecture.

A second consideration to have emerged from many of the studies already published is that the quality of the available archaeological record is of crucial importance when it comes to the detection and interpretation of this 
sort of material evidence (S. Gutiérrez, A. Vigil-Escalera, E. Peytremann). The very nature of early medieval domestic architecture, characterised by relatively short periods of use, transformation and re-use, by its distribution over wide surface areas generating a low intensity of vertical stratigraphy, and by the use of fragile materials and simple techniques, means that its material attributes are very different to those from other periods, and, moreover, that they present certain similarities with protohistoric domestic architecture. Post-depositional processes also condition, in large measure, the levels of conservation of these buildings: in the case of abandoned sites, the mechanisation of farming practices has caused notable destruction, while many sites which have been occupied until contemporary times have been affected by more recent building activity. ${ }^{6}$ Due to all of these disturbances it is very often the case that floors or original levels of occupation of such buildings have not been well conserved, or that original levels have been lost entirely, with the changes of surface colouration that have been preserved allowing us to identify the position of posts or paraments of various sorts. This being the case, the conditions of conservation of domestic deposits determine the sort of analyses which can be undertaken, as the work of Alfonso Vigil-Escalera, dedicated to hearths and ovens, or the work on Portuguese domestic architecture already discussed, makes clear. One can thus establish a direct relationship between the improvement, in qualitative terms, of archaeological practice that has taken place in recent decades, and the evaluation and study of this sort of architecture, given that it is our method of working which determines the visibility of the material evidence and our capacity to understand critically the formative processes of archaeological deposits, or the integrated study of the bioarchaeological record, which together allow us to offer certain social or functional hypotheses. Accordingly, the archaeological visibility of architecture and of associated domestic deposits are the factors that determine the sort of interpretations that one can make in each case.

Thirdly, it is striking that the greater part of the syntheses on domestic architecture have been dedicated substantially to material related to forms of construction, extended to include morphological, taxonomic, and technological aspects, and, in the second instance, to the

\footnotetext{
${ }^{6}$ At any rate, the explanations are very variable; in many rural contexts in the Basque Country rural sites are heavily devastated due to recent agrarian activities while in the project of the Cathedral of Santa María de Vitoria-Gasteiz very well conserved structures have been recovered (Azkarate, Solaún 2009), perhaps because the area has been preserved thanks to its later religious use.
}

functional aspects of architecture (e.g. Brogiolo 1994, $7-$ 11; Hamerow 2002, 12-51; Peytremann 2003, 274-295; Tipper 2004; Brogiolo 2008, 10-19). Beyond the understandable need to identify and systematise different types of structure, I believe that this prevalence could be explained - at least in part - by the fact that many archaeological schools in western Europe, especially in the south, are very influenced by materialist theoretical approaches, the roots of which tap in to processualist anthropological approaches which emerged in the 1970s, the foundational phase of postclassical archaeology in the Mediterranean.

Fourth, while bearing in mind the existence of notable geographical and chronological diversity, it is nonetheless surprising that certain techniques and types of domestic constructions are found in practically all of western Europe, although there are also lacunae and differences which are very significant. Almost all studies show that wood was the dominant building material throughout the early Middle Ages, with the exception of the most southerly areas of Italy or Iberia. The use of clay and stone was also frequent, although differences in this respect are best brought out on a regional scale. Although in some European areas buildings with plinth foundations and stone elevations identify churches, palaces, or elite spaces, as is the case in the well known two-storey buildings in Italian cities (Santangeli Valenzani 2011) or British and German churches, in sites such as El Tolmo de Minateda this sort of material is used in ordinary dwellings.

Equally compelling is the pre-eminence of dwellings built with supporting frame posts situated at floor level and the notable frequency of Sunken-Feature Buildings, which have been recognised in all of the territories analysed, although their presence is as of yet less frequent in southern sectors, such as those that were under Byzantine domination (Arthur, 2010; Quirós Castillo 2011). On the other hand, large buildings known as longhouses, very common in central Europe, seem to be absent from more peripheral continental areas, given that they are unknown in Great Britain, only furnish three examples in Iberia (in the Basque Country) and the few Italian examples we have are located in Tuscany alone. However, in the absence of systematic phosphate analysis it is not always easy to identify the specific function of these large buildings located in the south of Europe. It is for this reason, for example, that Giovanna Bianchi proposes in her study to analyse some of these buildings with regard to their communal aspect as opposed to an interpretation which identifies these buildings as elite residences. This notwith- 
standing, our Iberian examples seem to allow to us defend an interpretation along these lines of social hierarchy (Quirós Castillo 2013).

This is, in fact, another of the principal problems we face when we undertake a comparative analysis of this sort of architecture on a European scale: namely, the construction of archaeological frameworks and of common categories of analysis. It is beyond doubt that we still lack systematic collections of data and that the majority of archaeological interventions carried out in recent years remain unpublished. For this reason the writing of studies aiming at more global syntheses is so very relevant and necessary, a good example of which is that of E. Peytremann on northern France (Peytremann 2003) or recent Ireland studies (O'Sullivan et alii 2010). But we also need to remain cautious. S. Gutiérrez confronts in her study a risk which derives from the use of simple morphological descriptive terms when building social models. It should be evident that formal analogies need not necessarily provide social and interpretative analogies, and it is thus essential that we build dense archaeological records which integrate bioarchaeological records and other forms of material evidence so as to allow us to define, in all their complexity, forms of dwelling and lifestyle practices in social terms (Quirós Castillo 2013).

And this reflection leads us to another fundamental consideration; the identification of the residences of elites and the archaeological analysis of the social hierarchies of the early Middle Ages via the prism of the architecture of the domestic sphere. Specialists are largely in agreement that social hierarchies of the early Middle Ages were more fluid and to some extent ambiguous (even opaque); this had much to do with the absence of strong states, and, as a corollary of this, the opportunity to move through the ranks, gaining social 'promotion' (Wickham 2005). In architectural terms, a profound imbalance is observable between aristocratic rural residences, such as the palace at Pla de Nadal in Valencia (Juan 2007), Anglo-Saxon halls (Hamerow 2011, 141-143) or longhouses, and the houses of the rest of the population (e.g. Santangeli Valenzani 2011 64-66). Did the middling sort disappear? Did houses not constitute a barometer of social status in the early Middle Ages? Is it possible to tell the difference between the house of a free peasant and a dependent peasant? How might we explain the apparent invisibility in material terms of social hierarchies? There is no simple answer to these questions, although written documentation (where it has been conserved) indicates that early medieval societies were complex and highly structured.
Giovanna Bianchi suggests in her study that we go beyond the analysis of building methods and pay more attention to dwelling, given that «the value of architecture resides, above all, in its interior». This author maintains, moreover, that in technological terms this sort of architecture is the fruit of selected cycles of production, which permits the creation of a productive space, and methods of material self-promotion, which are much less rigid and normativised when it comes to the display of certain social markers or types of building.

On the other hand, not all archaeological markers have the same value and although scholars have frequently paid more attention to the representation of power than the exercise of power (Quirós Castillo 2013), definitions of aristocratic lifestyles must take into account the differences which allow us to understand social logics and actors (methods of storage, patterns of consumption, methods of managing non-agrarian production) (Loveluck 2011).

In sixth place, another consequence to derive from the apparent homogeneity of early medieval systems of domestic building is that of the existence of different 'traditions of construction' in Mannoni's terms which apparently acquire notable protagonism in the post-Imperial period. Inevitably this debate is intertwined with that which questions the role of 'barbarians' in the transformation of early medieval societies. Many are the authors who have associated and continue to associate the distribution of certain types of building, such as Sunken-Feature Buildings or longhouses, with the presence of non-indigenous groups (e.g. Brogiolo 2008, 2011; Fronza 2011). Mark Gardiner, Edith Peytremann and Rainer Schreg all draw attention in their studies to the difficulties inherent in this sort of interpretation, given that the evidence is often contradictory and «ethnic traditions» not very visible. In fact, many authors have emphasised the existence of similar types of constructions from the pre-Roman and Roman periods, or in areas not subject to the overlordship of «barbarians» (Arthur 2010; Santangeli Valenzani 2011; Hamerow 2011; Quirós Castillo 2011). Sometimes the chronological and spatial distribution of these types of construction does not appear to cohere neatly with the distribution of German peoples. But in reality what is at stake is the viability and the usefulness of an historicist paradigm as a means of interpreting the architectural record in archaeological terms.

And so we turn to our seventh and last point of analysis. The study and interpretation of domestic architecture has, as one would expect, important theoretical implications in light of the fact that, as some authors have 
signalled, "archaeologists excavate the dwellings and domestic artefacts, not the social units» (Wilk, Rathje 1982b, 618). Throughout this text the theoretical implications of this subject matter have steadily come to the fore, as have the assumptions made with regard to early medieval domestic architecture; furthermore, proposed in many of the studies collected herein have been interpretations which stress a transfer of focus from the study of forms of building to the analysis of forms of dwelling. It is certain that the early medieval domestic architectural record often presents specific limitations which make it more difficult to posit hypotheses, but in any case it remains important to analyse these constructions while bearing in mind the conceptual baggage that archaeology has acquired in recent decades.

In the study of domestic architecture a whole series of very heterogeneous epistemological and disciplinary traditions converge, which can be identified in the approaches common to the history of architecture, vernacular architecture, historical geography, anthropology, ethnography and of course archaeology. And even though the archaeology of architecture is «in fact...the oldest form of archaeology» (Morriss 2000, 6), the explicit conceptualisation of an archaeology of domestic architecture and of the domestic environment can only be traced to recent decades, and especially to Great Britain, insofar as scholarly research is concerned ${ }^{7}$.

Since at least the 1980s processual archaeology has conceptualised an archaeology of the domestic environment (household archaeology) understood as a micro-scale analysis via which it was possible to overcome «the existing 'mid-level theory gap' in archaeology» (Wilk, Rathje 1982a, 617). At the Society of American Archaeology's 1981 conference dedicated to 'household archaeology' certain seminal studies were presented, which included, for example, contributions of a clearly functionalist bent inclining towards the identification of general principles that underlie processes of production, distribution, transmission and reproduction (Wilk, Rathje 1982b), and also studies influenced by historical materialism (Rathje, McGuire 1982). And although household archaeology continues to be marginal to the practice of processual archaeology (Tringham 2001, 6928), the former has managed to create a dense and complex notion of 'the domestic' which has served to guide a large number of investigations in such a way that they have been able to

\footnotetext{
${ }^{7}$ The bibliography is vast; here only summaries on 'household archaeology' are
} cited (Steadman 1996, 54 and passim; Tringham 2001; Allison 2008). integrate the analysis of architecture into a broad and ambitious interpretative framework.

Nonetheless, the most significant contributions have emerged, since the 1990s, from post-processualist paradigms. One of the most prolific areas of the study of historical domestic architecture in recent times has been the study of vernacular architecture. In issue 28 of the journal 'Vernacular Architecture', Christopher Dyer painted in historical terms an intriguing picture of the contribution that the study of vernacular architecture has had, underlining in particular social, economic and mental aspects (Dyer 1997). It was M. Johnson, however, the author of several fundamental studies on late and postmedieval English domestic architecture, who proposed in a short and brilliant article published in this very journal a definitive guide titled "principles of Vernacular Architectural Studies», on the back of which a dense plan of future research, strongly post-processualist in character, was built (Johnson 1997). His later works have developed these approaches and drawn attention to concepts such as performance, materiality and agency (Johnson 2010).

Other approaches have not enjoyed, thus far, a significant influence in the study of domestic architecture. One of the most promising avenues is South American social archaeology and others Marxism's traditions, which is making important theoretical contributions, conceptualizing architecture as a technology of power, and analysing post-medieval and contemporary contexts (e.g. Funari, Zarankin 2002; Sweitz 2012). Similarly, in the 1990s, three important volumes on household archaeology were published, introducing new structuralist, contextual, neomarxist and symbolic perspectives to the study of domestic spaces (Kent 1990, Samson 1990, Allison 1999). But, as was the case with regard to the processualist paradigm, household archaeology has also not managed to become one of the central prisms of analysis until recent years (Pluckhahn 2010, Carballo 2011), given that, for authors come P. Allison «archaeological data are not always capable of answering the kinds of questions which anthropologists and social historians might ask of their own data» (Allison 2008, 1457).

In short, the archaeological analysis of domestic architecture has set about building a whole series of analytical categories and conceptual mechanisms in recent decades with the aim of overcoming the material aspect of buildings, of stressing the social activity that developed at the domestic level, and of analysing the village ecosystem to which R. Schreg refers in his study, or, to call it by another name, to pay as much attention to forms of dwelling as to 
forms of buildings. Many of these tools, still not applied in systematic fashion to the analysis of early medieval domestic architecture, are very useful in our effort to overcome the risk - indicated by Edith Peytremann - supposed by the growing accumulation of high quality records, which share substantial similarities. Urban archaeology is a mirror in which we can observe ourselves so as not to commit the same mistakes again.

4. To conclude these notes I would like to underline that the texts collected herein confirm that archaeology finds itself at a true crossroads. The collapse of the postprocessualist paradigm, buried by the difficulty implied by the negotiation of subjectivism and the atomisation of narrative, and by a model of the organisation of cultural heritage which tends to produce repetitive documents without fostering mechanisms of control which promote less frequent and better interventions within a responsibly planned framework, threatens to bring to an end one of the most prolific periods of archaeological praxis in western Europe. The development which early medieval domestic architecture is currently experiencing is the fruit of this period which now seems to be grinding to a halt. Almost all of the studies that comprise this dossier suggest new avenues and approaches; a situation which reflects the dissatisfaction provoked by the meagre knowledge we still possess with regard to the houses of this period, and by the limits of some of the approaches which have been followed hitherto.

I believe that the practitioners of the archaeology of architectures must also be willing to broaden their methodologies, their areas of intervention and their ways of thinking. In the same way that architecture is much more than a few walls that demarcate an area of space, the archaeology of architectures - which has been developed in the south of Europe in close relation to a certain conceptual and cultural framework - must push us to rethink the very notion of architecture and of the built environment in multidimensional terms, for as P. Bourdieu has underlined, «the house is not only a physical space, but a space whose use varies with time» (Bourdieu 1972).

\section{Acknowledgements}

I am grateful to the anonymous referees for their valuable suggestions and Robb Portass for the translation of the paper.

\section{References}

Allison P. M. (ed), 1999, The archaeology of household activities, London.

Allison P., 2008, "Household Archaeology», in D. M. Pearsall (ed), Encyclopedia of Archaeology, London, pp. 1449-1458.
Arthur P., 2010, "Edilizia residenziale in età medievale nell'Italia meridionale», en P. Galetti (a cura di), Edilizia residenziale fra $I X-X$ secolo. Storia $e$ Archeologia, Firenze, pp. 31-58.

Azkarate A., Quirós Castillo J. A., 2001, «Arquitectura doméstica altomedieval en la Península Ibérica. Reflexiones a partir de las excavaciones arqueológicas de la catedral de Santa María de Vitoria-Gasteiz», Archeologia Medievale XXVII, pp. 25-60.

Azkarate A., Quirós Castillo J. A. (eds), 2005, «Aparejos constructivos medievales en el Mediterráneo Occidental. Estudio arqueológico de las técnicas constructivas", Arqueología de la Arquitectura 4, pp. 7-249.

Azkarate A., Solaun J. L., 2009, «Nacimiento y transformación de un asentamiento altomedieval en un futuro centro de poder: Gasteiz desde fines del siglo VII d.C. a inicios del segundo milenio», J. A. Quirós Castillo (ed), The archaeology of Early Medieval Villages in Europe, Bilbao, pp. 405-428.

Belarte N. C., 2008, «Domestic architecture and social differences in northeastern Iberia during the Iron Age (c. 525-200 B C)», Oxford Journal of Archaeology 27.3, pp. 175-199.

Beltrán de Heredia Bercero J., 2009, «Arquitectura y sistemas de construcción en Barcino durante la Antigüedad Tardía. Materiales, técnicas y morteros: un fósil director en el yacimiento de la Plaza del Rey», Quarhis 5, pp. 142-169

Bordieu P., 1972, Esquisse d'une théorie de la pratique, Paris.

Brogiolo G P., Gelichi S., 1988, La città nell'alto Medioevo italiano. Archeologia e Storia, Roma-Bari.

Brogiolo G. P. (a cura di), 1994, Edilizia residenziale tra Ve VIII secolo, Mantova.

Brogiolo G. P., 2008, "Aspetti e prospettive di ricerca sulle architetture altomedievali tra VII e X secolo (Monselice, Ca'Emo, 22 maggio 2008)», Archeologia Medievale XXXV, pp. 9-22.

Brogiolo G. P., 2011, Le origini della città medievale, Mantova.

Buko A., 2010, «Edilizia residenziale in Europa centro-settentrionale (secoli IX$\mathrm{X})$ », P. Galetti (a cura di), Edilizia residenziale tra $I X-X$ secolo. Storia e Archeologia, Firenze, pp. 199-221.

Cañavate Castejón V., 2008, Estructuras domestica de época altomedieval en el Sureste peninsular: El Tolmo de Minateda (Hellin, Albacete), Albacete.

Carballo D. M., 2011, "Advances in household archaeology in Highland Mesoamerica", Journal of Archaeological Research 19.2, pp. 133-189.

Chapelot J., Fossier R., 1980, Le village et la maison au Moyen Age, Paris.

Christie N., Stamper P. (ed), 2012, Medieval rural settlement. Britain and Ireland, AD 800-1600, Oxford.

Donat P., 1980, Haus, Hof und Dorf in Mitteleuropa vom 7. Bis 12. Jahrhundert. Archäologische Beitrage zur Entwicklung und Struktur der bäuerlichen Siedlung, Berlín

Dyer C., 1997, "History and Vernacular Architecture», Vernacular Architecture 28 , pp. $1-8$.

Francovich R., Hodges R., 2003, Villa to Villages. The transformation of the Roman countryside in Italy, c. 400-1000, London.

Fronza V., 2011, «Edilizia in materiali deperibili nell'alto medioevo italiano: metodologie e casi di studio per un'agenda della ricerca", Post-Classical Archaeologies 1, pp. 95-138.

Funari P., Zarankin P., 2003, An social archaeology of housing from a Latin American perspective: a case study», Journal of Social Archaeology. 3: 23-45.

Gutiérrez Lloret S., 2000, «El espacio domestico altomedieval del Tolmo de Minateda (Hellín Albacete) entre el ámbito urbano y rural», A. Bazzana, E. Hubert (ed), Castrum 6. Maisons et espaces domestiques dans le monde méditerranéen au Moyen Âge, Roma-Madrid, pp. 151-164.

Gutiérrez Lloret S., Cañavate Castejón V., 2010, «Casas y cosas : espacios y funcionalidad en las viviendas emirales del Tolmo de Minateda (Hellín, Albacete)", Cuadernos de Madinat al-Zahra 7, pp. 123-148.

Hamerow H., 2002, Early Medieval Settlements. The Archaeology of Rural Communities in North-West Europe 400-900, Oxford.

Hamerow H., 2011, "Anglo-Saxon timber buildings ant their social context», H. Hamerow, D. A. Hinton, S. Crawford (ed), The Oxford handbook of AngloSaxon Archaeology, Oxford, pp. 128-155.

Hamerow H., 2012, Rural Settlements and Society in Anglo-Saxon England, Oxford.

Johnson M., 1997, "Vernacular Architecture: the loss of innocence», Vernacular Architecture 28, pp. 13-19. 
Johnson M., 2010, English houses 1300-1800: vernacular architecture, social life, London.

Jones I., 2012, The use of social space in Early Medieval Irish Houses with particular reference to Ulster, BAR British Series 564, Oxford.

Juan E., 2007, «Pla de Nadal: una villa aulica di epoca visigota», G. P. Brogiolo, A. Chavarria Aranu (a cura di), I Longobardi. Dalla caduta dell'Impero all'alba dell'Italia, Milano, pp. 146-147.

Kent S. (ed.) 2001, Domestic Architecture and the Use of Space, Cambridge University Press. Cambridge

Klápště J. (ed) 2002, Ruralia IV. The rural house from the migration period to the oldest still standing buildings, Conference proceedings, Praga.

Klápště J., Nissen Jaubert A., 2007, «Rural Settlement», J. Graham-Campbell, M. Valor (ed), The Archaeology of Medieval Europe, Vol. 1, Eighth to Twelfth Centuries $A D$, Aarhus, pp. 76-110.

Loveluck C. P., 2011, «Problems of the definition and conceptualisation of early medieval elites, AD 450-900: the dynamics of the archaeological evidence», R. Le Jan, F. Bougard and H. W. Goetz, ed. Théories et Pratiques des Élites au Haut Moyen Age. Conception, Perception et Réalisation Sociale, Turnout, pp. 2167.

Malpica Cuello A., 2010, «Edilizia residenziale musulmana del IX e X secolo», P. Galetti (a cura di), Edilizia residenziale tra IX-X secolo. Storia e Archeologia, Firenze, pp. 223-244.

Morriss R. K., 2000, The archaeology of buildings, Stroud.

O'Sullivan A., McCormick F., Harney L., Kinsella J., Kerr T., 2010, Early Medieval Dwellings and Settlement in Ireland, AD 400-110, Early Medieval Archaeology Project (EMAP) Report 4.2 http://www.ucd.ie/archaeology/ documentstore/allreports/emap_report_4.2vol1_print.pdf (consulted 11.10.2012)

Peytremann E., 2003, Archéologie de l'habitat rural dans le nord de la France du IV au XII siècle, Saint-Germain-en-Laye.

Pluckhahn T. J., 2010, «Household Archaeology in the Southeastern United States: History, Trends, and Challenges", Journal of Archaeological Research 18.4, pp. 331-385.

Quirós Castillo J. A., 2011, «La arquitectura doméstica de los yacimientos rurales en torno al año 711", Zona Arqueológica 15.2, pp. 63-82.

Quirós Castillo J. A., 2013, «Archaeology of power and hierarchies in early medieval villages in North of Spain», Ruralia IX, forthcoming.

Rathje W. L., McGuire R. H., 1982, «Rich Men...Poor Men», American Behavioral Scientist 25.6, pp. 705-715.

Roig Buxó J., 2009, «Asentamientos rurales y poblados tardoantiguos y altomedievales en Cataluña (siglos VI al X)», J. A. Quirós Castillo (ed), The archaeology of Early Medieval Villages in Europe, Bilbao, pp. 207-251.

Salvatierra Cuenca V., Castillo J. C., 2000, Los asentamientos emirales de Peñaflor y Miguelico (Jaén), Jaén.

Samson R. (ed), 1990, The Social Archaeology of Houses, Edinburgh.

Sánchez J., 1998, «La Arqueología de la Arquitectura. Aplicación de nuevos modelos de análisis a estructuras de la Alta Andalucía en época ibérica", Trabajos de Prehistoria 55.2, pp. 89-109.
Santangeli Valenzani R., 2011, Edilizia residenziale in Italia nell'altomedioevo, Roma.

Steadman S. R., 1996, "Recent research in the Archaeology of Architecture: Beyond the foundations", Journal of Archaeological Research 4.1, pp. 51-93.

Sweitz S. R., 2012, On the Periphery of the Periphery. Household Archaeology at Hacienda San Juan Baustista Tabi, Yucatán, Mexico, London.

Tente C., 2011, «Do século IX ao XI no alto vale do Mondego (Guarda, Porgual): Dinâmicas de povoamento e estruturas sociais», Debates de Arqueologia Medieval 1 pp. 23-44.

Tipper J., 2004, The Grubehaus in Anglo-Saxon England An analysis and interpretation of the evidence from a most distinctive building type, Oxford.

Tringham R., 2001, «Household Archaeology», N. J. Smelser, P. B. Baltes (ed), International Encyclopaedia of the Social \& Behavioural Sciences, London, pp. 6925-6929.

Vela Cossio F., 1995, «Para una prehistoria de la vivienda. Aproximación historiográfica y metodológica al estudio del espacio doméstico prehistórico", Complutum 6, pp. 257-276.

Vigil-Escalera Guirado A., 1999, «La Indiana (Pinto, Madrid). Estructuras de habitación, almacenamiento, hidráulicas y sepulcrales de los siglos VI-IX en la Marca Media», XXIV Congreso Nacional de Arqueología, Murcia, vol. 5, pp. 205-211.

Vigil-Escalera Guirado A., 2000, "Cabañas de época visigoda: evidencias arqueológicas del Sur de Madrid. Tipología, elementos de datación y discusión", Archivo Español de Arqueología 73, pp. 245-274.

Vigil-Escalera Guirado A., 2003, «Arquitectura de tierra, piedra y madera en Madrid (ss. V-IX d. C.). Variables materiales, consideraciones sociales», Arqueología de la Arquitectura 2, pp. 287-291.

Vizcaíno J., 2009, La presencia bizantina en Hispania (siglos VI-VII). La documentación arqueológica, Murcia

Ward-Perkins B., 1981, "Two byzantine houses in Luni», Papers of the British School at Rome XLIX, pp. 91-98.

Ward-Perkins B., 2005, The fall of Rome and the end of civilization, Oxford.

Wickham C., 2005, Framing the Early Middle Ages. Europe and the Mediterranean 400-800, Oxford

Wilk R. R., Rathje W. L. (ed), 1982a, "Archaeology of the Household", American Behavioral Scientist 25.6, pp. 613-724.

Wilk R. R., Rathje W. L., 1982b, «Household Archaeology», American Behavioral Scientist 25.6, pp. 617-639.

Zarankin A., 1999, «Arqueología de la Arquitectura. Another brick in the wall», Revista do Museu de Arqueologia e Etnologia, São Paulo, Suplemento 3, pp. 119128.

Zimmermann W. H., 1992, Die Siedlungen des 1. bis 6. Jh. n. Christus von Flögeln-Eekhöltjen, Niedersachsen: Die Bauformen und ibre Funktionen. Probleme der Küstenforschung im Südlichen Nordseegebiet bd.19, Hildesheim.

Zimmermann W. H., 1998, Pfosten, Ständer und Schwelle und der Übergang vom Pfosten -zum Ständerbau: Eine Studie zu Innovation und Beharrung im Hausbau. Zu Konstruktion und Haltbarkeit prähistorischer bis neuzeitlicher Holzbauten von den Nord-und Ostseeländern bis zu den Alpen, Oldenburg.

Recibido: 3 de julio de 2012 Aceptado: 23 de octubre de 2012 